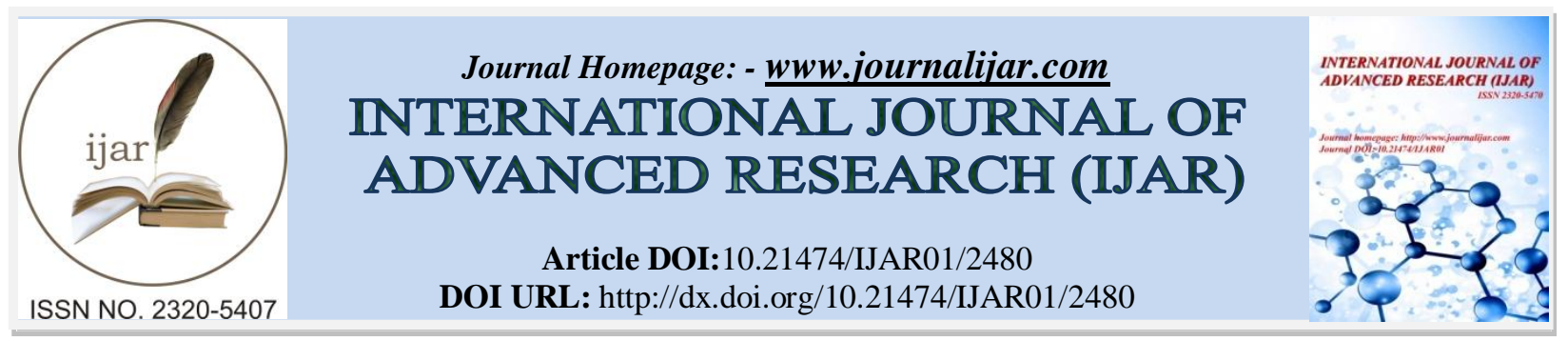

RESEARCH ARTICLE

\title{
WEED MANAGEMENT PRACTICES ON WEED CONTROL EFFICIENCY AND YIELD OF BLACKGRAM
}

\author{
S. Marimuthu ${ }^{1}$, N. S. Venkataraman ${ }^{2}$ and S. Sanbagavalli ${ }^{3}$. \\ 1. Ph.D. Scholar, Department of Agronomy, Tamil Nadu Agricultural University, Coimbatore - 641003, India. \\ 2. Professor and Head, Department of Agronomy, Agricultural College and Research Institute, \\ Tamil Nadu Agricultural University, Madurai - 625104, India. \\ 3. Assistant Professor, Department of Pulses, Tamil Nadu Agricultural University, Coimbatore - 641003, India.
}

\section{Manuscript Info}

\section{Manuscript History}

Received: 23 October 2016

Final Accepted: 21 November 2016

Published: December 2016

\section{Key words:-}

Pendimethalin, Imazethapyr, Quizalofop ethyl, weed control efficiency, yield.

\section{Abstract}

Afield experiment was conducted on sandy clay loamy soil during the rabiand summer season of 2011-2012 at Agricultural College and Research Institute, Madurai, Tamil Nadu to evaluate the effective weed management practices in blackgram. The experiment comprising of eleven weed management treatments were conducted in a randomized block design and replicated thrice. The treatments involving pre-emergence herbicide viz., pendimethalin and postemergence herbicide viz., imazethapyr, quizalofop-ethyl and in combination with hand weeding once. In addition, hand weeding twice at 15 and 30 DAS were tested with unweeded check. The results revealed that higher seed $(1431 \mathrm{~kg} / \mathrm{ha}$ in rabi and $1493 \mathrm{~kg} / \mathrm{ha}$ in summer) yield and higher weed control efficiency were recorded under application of pendimethalin $(0.75 \mathrm{~kg} / \mathrm{ha})$ as pre emergence at 3 DAS followed by (fb) mixture of imazethapyr ( $50 \mathrm{~g} / \mathrm{ha})+$ quizalofopethyl (50 g/ha) as post emergence at 20 days after sowing (DAS) and which was comparable with pre emergence application of pendimethalin $\mathrm{fb}$ half the dose mixture of above mentioned post emergence herbicides. The control treatment, more weed growth observed throughout the crop growing period caused 62 and 58 per cent reduction in seed yield during both rabiand summer seasons respectively. Based on the results, it can be concluded that application pendimethalin followed by imazethapyr + quizalofop-ethyl enhanced the weed control efficiency and also an effective weed management practice with respect to yield and cost for the blackgram.

Copy Right, IJAR, 2016,. All rights reserved.

\section{Introduction:-}

Blackgram is grown all over the world, mostly in tropical and sub-tropical countries for grains, green manuring, fodder and forage as sole crop, intercrop, mixed crop and in sequential cropping systems. The low levels of availability of legume grains could be mitigated not only by increasing the production but also by minimizing the quantitative and qualitative losses of grain by weeds through their control (Adpawaret al., 2011). As the crop itself getting less attention, weed control is more neglected and further reduces the production. Parvenderet al. (2008) reported that weeds infestation is not checked after 20 days after sowing (DAS), severe yield reduction to the extent 
of 38 per cent was recorded in contrast to 20 per cent yield reduction with unchecked weed infestation till 20 DAS. Weed control is one of the essential agronomic measures to exploit the maximum yield potential of the newly developed high yielding varieties (Singh et al., 2002). The need for adequate weed control measures is emphasized by the fact that weeds cause more damage to crops than all plant pests and diseases put together. The time honored practice of hand weeding is usually carried out only after sufficient damage by weed to crop. Moreover hand weeding, which is becoming expensive (Patel et al., 2011). This requires dependence on increased number of labour during peak period of sowing and harvesting. Solution for these hurdles lies in the use of herbicides with the advent of modern technology in agriculture, the use of herbicides has become a common practice for early effective and selective weed control in crop plants (Kachhadiyaet al., 2009). Keeping this in view, the present investigation was under taken to evaluate the effective and economic weed management as well as higher crop productivity in irrigated blackgram during both rabiand summer season.

\section{Materials and Methods:-}

A field experiment was conducted during rabiand summer season 2011 to 2012 at Agricultural College and Research Institute, Tamil Nadu Agricultural University, Madurai. The experimental soil was sandy clay loam with a $\mathrm{pH}$ of 7.01, low in nitrogen, medium in phosphorus, high in potassium. The experiment was laid out in randomized block design with eleven treatments and replicated thrice. The treatments involving pre-emergence herbicide viz., pendimethalin was made at $0.75 \mathrm{~kg} / \mathrm{ha}$ and post-emergence herbicide viz., imazethapyr, quizalofop-ethyl was made at 50 and $25 \mathrm{~g} / \mathrm{ha}$ and in combination with hand weeding once. In addition, hand weeding twice at 15 and 30 DAS were tested with unweeded check. In order to maintain uniformity in plant population, the seeds of blackgram VBN (Bg) 5 was treated with rhizobium and dibbled by adopting a spacing of $30 \mathrm{~cm} \times 10 \mathrm{~cm}$.Nitrogen (N), phosphorus $\left(\mathrm{P}_{2} \mathrm{O}_{5}\right)$, potassium $\left(\mathrm{K}_{2} \mathrm{O}\right) @ 25: 50: 25 \mathrm{~kg} / \mathrm{ha}$ was applied in the form of urea, single super phosphate and muriate of potash during the final land preparation or before sowing the seeds. Pre emergence herbicides were applied at 3 DAS and as post emergence herbicide at 20 DAS using knap sack sprayer fitted with a flat pan nozzle with 500 litres of water/ha. Observations on weed density were recorded with the help of a quadrant $0.25 \mathrm{~m}^{2}$ placed randomly at four place in each plot. The growth, yield attributes and yields were recorded from five selected plants in each plot. The treatment differences were worked out at five per cent probability level.

\section{Weed control efficiency (WCE)}

Weed control efficiency was calculated as per the procedure given by Mani et al. (1973).

$$
\operatorname{WCE}(\%)=\frac{\mathrm{WDWc}-\mathrm{WDWt}}{\mathrm{WDWc}} \times 100
$$

Where,

WCE - Weed control efficiency in percentage

WDWc - Dry weight $\left(\mathrm{g} / \mathrm{m}^{2}\right)$ of weeds in unweeded check

WDWt - Dry weight $\left(\mathrm{g} / \mathrm{m}^{2}\right)$ of weeds in weed control treatments

\section{Results and Discussion:-}

\section{Weed flora:-}

Weed flora of the experimental field was composite in nature consisting of grasses, sedges and broad leaved weeds. Grasses were more dominant (40.15 per cent) than the broad leaved weeds (36.43 per cent) and sedges (23.42 per cent). The weed flora found in the experimental fields mainly consisted of Echinochloacolonum, Echinocholacrusgalli, Cynodondactylon,Cyperusrotundus, Cyperusiria, Corchoruscapsularis, Trianthemaportulacastrum, Cleome viscosaand Ecliptaprostrata. Such wide spectrum of weeds in blackgram was reported by many workers (Patel et al., 2011 and Malliswariet al., 2008).

\section{Weed control efficiency (WCE):-}

Weed management through application of pre and post emergence herbicides reduced the weed dry weight and increased the WCE when compared to two hand weeding at 15 and 30 DAS throughout the crop period. Among the treatments, pre emergence application of pendimethalin $(0.75 \mathrm{~kg} / \mathrm{ha})$ at $3 \mathrm{DAS} \mathrm{fb}$ mixture of imazethapyr $(50 \mathrm{~g} / \mathrm{ha})+$ quizalofop ethyl $(50 \mathrm{~g} / \mathrm{ha})$ as post emergence on 20 DAS recorded higher weed control efficiency of 78 per cent in rabi and 77.94 per cent in summer and it was comparable with pre emergence application of pendimethalin @ $0.75 \mathrm{~kg} / \mathrm{ha}$ fb post emergence herbicide mixture of imazethapyr (25 g/ha) + quizalofop ethyl (25 g/ha) on $20 \mathrm{DAS}$ (Table 1). The maximum WCE obtained by the above promising weed management practices was due to greater reduction of grasses, sedges and broad leaved weeds in all the stages of crop growth itself which in turn increased 
the vigor and growth of blackgram resulted in good crop establishment. Similar findings were also reported by Hemrajet al. (2009) and (Rao, 2011).

Table 1:-Effect of weed control treatments on growth characters and weed control efficiency (WCE) of blackgram

\begin{tabular}{|c|c|c|c|c|c|c|c|}
\hline \multirow[b]{2}{*}{$\begin{array}{l}\text { T. } \\
\text { No }\end{array}$} & \multirow[b]{2}{*}{ Treatment } & \multicolumn{2}{|c|}{ Plant height (cm) } & \multicolumn{2}{|c|}{ DMP (kg/ha) } & \multicolumn{2}{|c|}{ WCE (\%) } \\
\hline & & $\begin{array}{c}\text { Rabi } \\
(\mathbf{2 0 1 1})\end{array}$ & $\begin{array}{c}\text { Summer } \\
(\mathbf{2 0 1 2})\end{array}$ & $\begin{array}{c}\text { Rabi } \\
(2011)\end{array}$ & $\begin{array}{c}\text { Summer } \\
(\mathbf{2 0 1 2})\end{array}$ & $\begin{array}{l}\text { Rabi } \\
(2011)\end{array}$ & $\begin{array}{c}\text { Summer } \\
(\mathbf{2 0 1 2})\end{array}$ \\
\hline $\mathbf{T}_{1}$ & $\begin{array}{l}\text { Pendimethalin@0.75 kg/ha as PE on } 3 \\
\text { DAS + HW on } 30 \text { DAS }\end{array}$ & 41.89 & 42.61 & 2145 & 2174 & 71.42 & 72.59 \\
\hline $\mathbf{T}_{2}$ & Imazethapyr@ 50 g/haas POE on 20 DAS & 39.12 & 39.20 & 2095 & 2107 & 59.93 & 62.24 \\
\hline $\mathbf{T}_{3}$ & $\begin{array}{l}\text { Quizalofop ethyl @ 50 g/haas POE on } 20 \\
\text { DAS }\end{array}$ & 38.95 & 39.01 & 2124 & 2127 & 59.53 & 62.46 \\
\hline $\mathbf{T}_{4}$ & $\begin{array}{l}\text { Pendimethalin@0.75 kg/ha as PE on } 3 \\
\text { DAS }+\mathrm{T}_{2}\end{array}$ & 43.67 & 43.82 & 2164 & 2209 & 71.16 & 72.75 \\
\hline $\mathbf{T}_{5}$ & $\begin{array}{l}\text { Pendimethalin@0.75 kg/ha as PE on } 3 \\
\text { DAS }+T_{3}\end{array}$ & 43.82 & 41.53 & 2158 & 2190 & 72.05 & 72.71 \\
\hline $\mathbf{T}_{6}$ & $\begin{array}{l}\text { Mixture of imazethapyr@ } 50 \mathrm{~g} / \mathrm{ha}+ \\
\text { quizalofop ethyl @ 50 g/ha as POE }\end{array}$ & 40.89 & 41.13 & 2020 & 2099 & 64.31 & 66.65 \\
\hline $\mathbf{T}_{7}$ & $\begin{array}{l}\text { Mixture of imazethapyr @ } 25 \mathrm{~g} / \mathrm{ha}+ \\
\text { quizalofop ethyl @ } 25 \mathrm{~g} / \mathrm{ha} \text { as POE }\end{array}$ & 40.75 & 41.58 & 2011 & 2068 & 64.07 & 66.48 \\
\hline $\mathbf{T}_{8}$ & $\begin{array}{l}\text { Pendimethalin@0.75 kg/ha as PE on } 3 \\
\text { DAS }+T_{6}\end{array}$ & 45.67 & 46.08 & 2296 & 2351 & 78.00 & 77.94 \\
\hline $\mathbf{T}_{9}$ & $\begin{array}{l}\text { Pendimethalin@0.75 kg/ha as PE on } 3 \\
\text { DAS }+T_{7}\end{array}$ & 44.90 & 45.67 & 2282 & 2318 & 77.76 & 77.90 \\
\hline$T_{10}$ & Hand weeding twiceat 15 and 30 DAS & 42.24 & 42.37 & 2163 & 2213 & 76.63 & 72.99 \\
\hline $\mathbf{T}_{11}$ & Un weeded check & 35.54 & 35.52 & 1439 & 1522 & 0.00 & 0.00 \\
\hline & SEd & 0.98 & 0.91 & 64 & 66 & - & - \\
\hline & $\mathrm{CD}(\mathrm{P}=0.05)$ & 2.04 & 1.90 & 128 & 132 & - & - \\
\hline
\end{tabular}

PE- Pre emergence, POE- Post emergence, DAS- Days after sowing

Table 2:- Effect of weed control treatments on yield attributes and yield of blackgram

\begin{tabular}{|c|c|c|c|c|c|c|c|c|}
\hline & \multicolumn{4}{|c|}{$R \mathbf{b b i} \mathbf{( 2 0 1 1})$} & \multicolumn{4}{|c|}{ Summer (2012) } \\
\cline { 2 - 9 } T.No & $\begin{array}{c}\text { Clusters } \\
\text { /plant }\end{array}$ & $\begin{array}{c}\text { No. of } \\
\text { pods/ } \\
\text { plant }\end{array}$ & $\begin{array}{c}\text { No. of } \\
\text { seeds/ } \\
\text { pod }\end{array}$ & $\begin{array}{c}\text { Yield } \\
\text { (kg/ha) }\end{array}$ & $\begin{array}{c}\text { Clusters } \\
\text { /plant }\end{array}$ & $\begin{array}{c}\text { No. of pods/ } \\
\text { plant }\end{array}$ & $\begin{array}{c}\text { No. of } \\
\text { seeds/ pod }\end{array}$ & $\begin{array}{c}\text { Yield } \\
\text { (kg/ha) }\end{array}$ \\
\hline $\mathbf{T}_{\mathbf{1}}$ & 7.12 & 27.98 & 4.90 & 992 & 7.45 & 28.12 & 4.94 & 1105 \\
\hline $\mathbf{T}_{\mathbf{2}}$ & 5.84 & 20.86 & 4.56 & 935 & 6.92 & 21.04 & 4.58 & 952 \\
\hline $\mathbf{T}_{\mathbf{3}}$ & 5.43 & 19.67 & 4.51 & 912 & 6.80 & 20.16 & 4.53 & 928 \\
\hline $\mathbf{T}_{\mathbf{4}}$ & 7.54 & 27.63 & 4.91 & 1002 & 7.72 & 28.23 & 5.01 & 1098 \\
\hline $\mathbf{T}_{\mathbf{5}}$ & 6.84 & 26.77 & 4.84 & 985 & 7.39 & 26.85 & 4.86 & 1006 \\
\hline $\mathbf{T}_{\mathbf{6}}$ & 6.61 & 25.23 & 4.76 & 1024 & 7.24 & 25.14 & 4.78 & 1055 \\
\hline $\mathbf{T}_{\mathbf{7}}$ & 6.37 & 24.44 & 4.60 & 975 & 7.20 & 24.46 & 4.64 & 989 \\
\hline $\mathbf{T}_{\mathbf{8}}$ & 7.86 & 31.61 & 5.17 & 1431 & 7.94 & 32.91 & 5.36 & 1493 \\
\hline $\mathbf{T}_{\mathbf{9}}$ & 7.77 & 29.99 & 5.08 & 1368 & 7.82 & 31.29 & 5.21 & 1453 \\
\hline $\mathbf{T}_{\mathbf{1 0}}$ & 7.21 & 28.33 & 5.00 & 1165 & 7.53 & 28.87 & 5.13 & 1249 \\
\hline $\mathbf{T}_{\mathbf{1 1}}$ & 3.29 & 12.41 & 3.41 & 582 & 3.14 & 16.23 & 3.43 & 626 \\
\hline $\mathbf{S E d}$ & 0.20 & 0.88 & 0.11 & 32 & 0.13 & 0.83 & 0.14 & 34 \\
\hline $\mathbf{C D}(\mathbf{P}=\mathbf{0 . 0 5})$ & 0.41 & 1.82 & 0.23 & 63 & 0.28 & 1.73 & 0.29 & 71 \\
\hline
\end{tabular}

Effect of weed control methods on crop growth characters:-

The growth characters like plant height and dry matter production were positively and significantly increased by various weed management treatments (Table 1). Pre emergence application of pendimethalin $(0.75 \mathrm{~kg} / \mathrm{ha}) \mathrm{fb}$ post emergence herbicide mixture of imazethapyr $(50 \mathrm{~g} / \mathrm{ha})+$ quizalofop-ethyl $(50 \mathrm{~g} / \mathrm{ha})$ on $20 \mathrm{DAS}$ recorded taller plants $(45.67$ and $46.08 \mathrm{~cm})$ and more dry matter production $(2296$ and $2351 \mathrm{~kg} / \mathrm{ha}$ ) which was comparable with pre emergence application of pendimethalin @ $0.75 \mathrm{~kg} / \mathrm{ha}$ fb half the dose mixture of above mentioned post emergence 
herbicides during rabi and summer season respectively. The increase in plant height at higher level of pre and post emergence herbicide might be due to the presence of adequate substrate for protein synthesis and stimulation of meristematic growth and provided better source for effective assimilation of synthates might be the cause for high dry matter production. This is in consistent with the findings of Shaikh et al. (2010) and Rao et al. (2010).

\section{Effect of weed management practices on yield parameters:-}

Among the various weed management methods, yield attributes viz., number of cluster/plant (7.86 and 7.94),number of pods/plant (31.61 and 32.91) and seed/pod (5.17 and 5.36) were significantly increased application of pendimethalin@ @ $0.75 \mathrm{~kg} / \mathrm{ha}$ as pre emergence fb mixture of imazethapyr + quizalofop ethyl each at $50 \mathrm{~g} / \mathrm{ha}$ on 20 DAS both in rabi and summer season respectively (Table 2) which was meticulously comparable with pendimethalin $(0.75 \mathrm{~kg} / \mathrm{ha})$ as pre emergence $\mathrm{fb}$ herbicide mixture of imazethapyr $(25 \mathrm{~g} / \mathrm{ha})$ and quizalofop ethyl $(25 \mathrm{~g} / \mathrm{ha})$ on $20 \mathrm{DAS}$. The above promising weed management practices were responsible for not only the reduction of weed growth but also to reduce the nutrient depletion by weeds and thereby increasing the nutrient uptake by crop throughout its life period. This type of congenial atmosphere created by the promising weed management practices helped the crop to obtain more number of pods /plant, seeds /plant of blackgram. The results are analogous to those reported by Patel et al. (2011) and Rao, (2011)

\section{Yield:-}

The increased seed yield of 1431 and $1493 \mathrm{~kg} / \mathrm{ha}$ were registered with the application of pendimethalin $(0.75 \mathrm{~kg} / \mathrm{ha})$ as pre emergence at $3 \mathrm{DAS}$ fb mixture of imazethapyr $(50 \mathrm{~g} / \mathrm{ha})+$ quizalofop ethyl $(50 \mathrm{~g} / \mathrm{ha})$ on $20 \mathrm{DAS}$ during $\mathrm{rabi}$ and summer season respectively (Table 2). This was followed by pre emergence application of pendimethalin @ $0.75 \mathrm{~kg} / \mathrm{ha}$ fb half dose mixture of above post emergence herbicides. This might be due to better control of all categories of weeds. In addition to that a uniform required plant population per unit area and increased number of leaves resulted in higher photosynthesis assimilation rates in metabolic activity and cell division which consequently increased the growth characters and yield attributes was maintained due to application of pre and post emergence herbicides. This resulted in lower nutrient depletion and lesser dry weight of weeds and thereby increasing the nutrient uptake of crop growth and yield attributes and seed yield of irrigated balckgram. These were in accordance with the earlier findings of Hemrajet al. (2009) and Naidu et al. (2011).

\section{Conclusion:-}

Based on the results of the above study, it was inferred that no single herbicide can solve the weed problem in irrigated blackgram. Therefore, a combination of pre emergence herbicide followed by a mixture of post emergence herbicides was essential for effective weed control. Under this situation, it can be recommended that application of pendimethalin at $0.75 \mathrm{~kg} / \mathrm{ha}$ as pre emergence at $3 \mathrm{DAS}$ fb application of mixture of imazethapyr and quizalofop ethyl each at $25 \mathrm{~g}$ or $50 \mathrm{~g} / \mathrm{haon} 20$ DAS for effective and economic weed management as well as higher crop productivity in irrigated blackgram during both rabiand summer season.

\section{References:-}

1. Adpawar, B.S., Karunakar, A.P., Parlawar, N.D. and Chavhan, K.R. (2011). Effect of weed management practices on productivity of blackgram. Res. on Crops. 12(1): 99-102.

2. Hemraj, D., Mundra, S.L. and Jain, N.K. (2009). Weed management in clusterbean [Cyamopsistetragonoloba (L.) Taub]. Indian J. Weed Sci., 41(3\&4): 224-227.

3. Kachhadiya, S.P., Savaliya, J.J., Bhalu, V.B., Pansuriya A.G. and Savaliya, S.G. (2009). Evaluation of new herbicides for weed management in chickpea (Cicerarietinum). Legume Res., 32 (4): 293-297.

4. Malliswari, T., Maheswara, R.P., Karuna, S.G. and Chadrika, V. (2008). Effect of irrigation and weed management practices on weed control and yield of blackgram. Indian J. Weed Sci., 40 (1\&2): 85-86.

5. Mani, V.S., Mala, M.L., Gautam, K.C. and Bhavandas. (1973). Weed killing chemicals in potato. Indian farming. 23(1): 17-18.

6. Naidu, K.R.K., Ramana, A.V., Veeraraghavaiah, R. and Ashoka Rani, Y. (2011). Effect of pre and postemergence herbicides o the control of Vicia sativa in rice-fallow blackgram [Vignamungo (L.) Hepper]. The Andhra Agric. J., 58 (1): 5-8.

7. Parvender, S., Sukhvinder, S., Virender, S. and Bawa, S.S. (2008). Studies on critical period of crop-weed competition in greengram in Kandi region of Punjab. Indian J. Dryland Agric. Res. and Dev., 23(1): 19-22.

8. Patel, B.D., Khedkar, H.P., Patel, R.B. and Sheta, B.T. (2011). Bio efficacy of some selective post emergence herbicide inkharif soybean. Res. on Crops. 12(2): 405-408. 
9. Rao, A.S. (2011). Bio-efficacy of quizalofop ethyl on Echinochloacolona control in rice fallow blackgram. The Andhra Agric. J., 58 (2): 130-132.

10. Rao, A.S., Subba Rao, G. and Ratnam, M. (2010). Copies bio-efficacy of sand mix application of pre mergence herbicides alone and in sequence with imazethapyr on weed control in relay crop of blackgram. Pak. J. Weed Sci. Res., 16(3): 279-285.

11. Shaikh, A.A., Desai, M.M., Shinde S.B. and Kamble, R.S. (2010). Yield and quality of soybean (Glycine max) as influenced by integrated weed management. Int. J. Agric. Sci., 6(2): 534-536.

12. Singh, V., Gautam, R.C. and Singh V.K. (2002). Effect of row spacing and weed management practices on the productivity of late planted urdbean. Indian J. Pulse Res., 15: 185. 